\title{
Div a zázrak v mayských poutích do Esquipulas*
}

\author{
JAN KAPUSTA**
}

Marvel and Miracle on Maya Pilgrimages to Esquipulas

\begin{abstract}
The study deals with pilgrimages to Esquipulas, Guatemala, and patterns of miracle in terms of their perception by the pilgrims reaching this prominent religious hub of Central America. Two key pilgrimage discourses are distinguished: traditional Maya pilgrimage, based on regular, calendar customs, and conventional Catholic pilgrimage, founded on occasional journeys to fulfil a vow. The Western understanding of miracle as a transgression of "natural laws" or "common course of nature" is relativized and contested arguing that the ethnographic evidence of Esquipulas shows not only different, but also opposite conceptions. Then, the study presents a spectrum of miracle ideas drawing from the Maya as well as European - the case of Lourdes is exemplary here - traditions in terms of the degree of their uncommonness. It is concluded that anthropology has to comprehend miracles as marvels in its cultural context; nevertheless, there is a widespread idea among many cultures that miracle is something wonderful, related to the awareness of non-obviousness of certain things and phenomena. Miracles find its content and meaning within particular cosmology, but, anchored in the psychological characteristics of the astonishment and the difference between usual and unusual or ordinary and extraordinary, they refer to features of human mind in a more general way.
\end{abstract}

Keywords: miracle, marvel, anthropology, pilgrimage, Mayas, Esquipulas, Lourdes

\section{Úvod}

„Zázrak může být přesně definován jako překročení zákona př́rody jednotlivým volním aktem božstva nebo zásahem nějakého neviditelného činitele", píše skotský filozof David Hume [1996 (1748): 160]. Tato slova z poloviny 18. století jsou ukázkou způsobu myšlení, které postupně opanuje západní kulturu, přinejmenším tu její část, jež se nazývá vědou. Předvádí obraz světa, v němž se orientujeme primárně podle svého smyslového poznání, zhodnoceného pravidly pravděpodobnosti a statistiky. Je to míra evidence, stupeň prokázání, co nás poučuje o světě a jeho prrírodních/přirozených zákonech.

Mým úmyslem není lícit a hodnotit na tomto místě Humovo filosofické řešení problému prokazování a existence zázraku. Rovněž nechávám stranou otázku př́rodní vědy nebo teologie po charakteru a možnosti, nebo naopak nemožnosti zázraku. Jde mi o kulturní pojetí tohoto jevu, chci analyzovat diskursy zázraku a to, co jím daní lidé v př́islušném časoprostoru míní. ${ }^{1}$ Povaha této studie bude v první řadě etnologická: její nejobsáhlejší částí část tvoří popis a interpretace pojetí zázraku v předním středoamerickém poutním

\footnotetext{
* Tento článek vznikl v rámci projektu „Rituál, obět a mobilita v současné mayské kultuře“, podpořeného Grantovou agenturou Univerzity Karlovy (GAUK) č. 253118.

** Mgr. Jan Kapusta, Ústav etnologie, Filozofická fakulta Univerzity Karlovy v Praze, Celetná 20, 11642 Praha. E-mail: kapusta.jan@seznam.cz

1 V antropologickém žargonu bychom hovořili o „emickém“ př́stupu, protikladném $\mathrm{k}$ „etickému“, jenž bez ohledu na nativní pohled analyzuje a zevšeobecňuje.
} 
místě Esquipulas. ${ }^{2} \mathrm{Na}$ obecnější rovině se pak práce dotýká problematiky kulturně ukotveného vnímání podivuhodnosti $\mathrm{z}$ hlediska narušení světaběhu či světařádu. ${ }^{3}$

Pokud jde o antropologii, o zázraku toho nebylo mnoho napsáno [Shanafelt 2004]. S nadsázkou řečeno, zázrak tematizuje zejména teologie, respektive přírodní věda, přičemž první zpravidla trvá na tom, že zázraky „jsou“, druhá pak, že „nejsou“. Každý tábor má přitom často na mysli dosti odlišné věci vycházející z velmi rozdílných kontextů a myšlenkových rámců. ${ }^{4}$ Skutečnost, že je koncept zázraku př́iliš specifický, až prríliš poplatný novověké evropské kultuře, náboženství a vědě, byla možná také důvodem, proč se tento pojem v antropologii neuchytil. To ale ani v nejmenším neznamená, že by se antropologové s tím, co je v současnosti označováno jako zázrak, při své práci nesetkávali. Právě naopak, nejednou totiž nacházejí svědectví o neviditelnosti, létání, proměně ve zvíře, ovládání počasí či bleskovém uzdravení smrtelné nemoci. Zpravidla však v takových případech nemluví o zázraku, zkrátka proto, že v daných kulturních kontextech nejde o nic nepochopitelného, zcela se vymykajícího specifické zkušenosti. Zázrak, jehož počátkem je údiv nad neobyčejným, nachází svůj obsah a význam jen v rámci určitých kulturních vzorců, $\mathrm{v}$ rámci daného rituálu, kosmologie a víry. A právě struktura obyčejného a neobyčejného, obvyklého a neobvyklého, možného a nemožného bude tvořit zastřešující téma této studie.

\section{Esquipulas}

Kdykoliv si položím otázku po zázraku, vzpomenu si na středoamerické poutní místo Esquipulas, které jsem při svém pobytu v Guatemale navštívil a o němž jsem slýchával i v těch nejzapadlejších koutech, zvláštním koloritem oplývající země. Ohniskem jeho slávy je socha tzv. Černého Krista, ${ }^{5}$ mayskými poutníky často nazývaného Milagroso, tedy Zázračný. Španělské slovo milagro (zázrak) Mayové přejali, avšak významy, které mu přikládají, jsou velmi rozmanité. Následující kapitoly představují pokus o porozumění tomu, co Milagroso pro Maye znamená, tj. proč za ním přicházejí a co od něho očekávají.

Malé městečko Esquipulas leží ve východní části Guatemalské vysočiny, při hranicích s Hondurasem. Centrálním prvkem původní dispozice obce zůstává severojižní hlavní třída spojující náměstí při kostelu sv. Jakuba, v němž dřive přebývala socha Černého Krista, s bazilikou, kde je umístěna poutní socha nyní. Tato symbolicky významná dispozice byla

2 Můj zájem o Esquipulas se zrodil při návštěvě tohoto „mayského“ poutního místa v listopadu 2009, v rámci sběru dat pro mou diplomovou práci. Tato studie je tak dalším krokem ve výzkumu poutnictví, rituálu a kosmologie současných Mayů a otevírá prostor pro pokračování terénní práce.

3 Antropologie se samozřejmě zabývá „zázrakem“ i v teoretické rovině. Zázrak pro antropologa existuje nejen jako kulturní realita či imaginární svět, ale také jako součást psychologických a sociálních procesů - např́ílad mechanismů léčení. Antropologie zná sílu imaginace a víry [Radin 1937], moc označení a odstranění nepř́ítele [Evans-Pritchard 1937], účinnost souznění protikladů [Lévi-Strauss 2006 (1958)], efektivitu liminální zkušenosti [Turner 2004 (1969)] nebo působení významu a smyslu [Geertz 2000 (1973)]. Ani etnologická snaha popsat a pochopit zázrak v kontextu dané kultury, ani antropologické úsilí o porozumění psychosociálním procesům a mechanismům jeho fungování však nemohou přesáhnout kompetence vědy: otázka existence, povahy a působení př́islušných duchů či božstev a víry v ně se pak s vědeckými otázkami míjí.

4 K současné debatě nad vztahem víry a vědy v souvislosti se zázrakem v rámci poutnictví, které se stalo hlavním předmětem tohoto článku, se nabízí například historická studie Lurd Ruth Harrisové [1999] či obecnější práce Roberta Scotta [2010].

5 Cristo Negro nebo také Señor de Esquipulas (Pán z Esquipulas). 
narušena stavbou silnice křížící hlavní třídu v pravém úhlu nedaleko před bazilikou. Tato cesta se stala novou „hlavní třídou“ plnou ubytovacích kapacit, restaurací, obchodů, ruchu a městského života obecně. Mezi silnicí a bazilikou dále vznikl velký park, jenž odděluje profánní město od sakrální půdy poutního střediska.

Socha Černého Krista od uznávaného sochaře Quiria Cataña byla umístěna v kapli nově založeného městečka Santiaga de Esquipulas roku 1595. Roku 1599 byla přemístěna do výše zmíněného kostela a v roce 1759 pak do baziliky, kde je podnes. Osobností, jež se v první polovině 18. století o vybudování honosné baziliky, stejně jako o oficiální uznání významu tohoto poutního místa, nejvíce zasloužila, byl guatemalský arcibiskup Pedro Pardo de Figueroa, kterého Kristus vyléčil a jehož ostatky jsou do dnešních dnů ve svatyni uloženy. Majestátní bělostná barokní bazilika se čtyřmi mohutnými věžemi se vypíná nejen nad město, nýbrž dominuje i celé rozlehlé přírodní pánvi obklopené věkovitými horami. Hlavnímu oltáři baziliky pak panuje socha Krista, jenž visí na stříbro-zlatém křiži s florálními motivy. Tyto motivy květin či vinné révy mají svou křestanskou symboliku, ale mohou odkazovat též k dávné symbolice kř́iže jakožto živoucího stromu. Kristus je doprovázen Pannou Marií, Máří Magdalenou a svým učedníkem Janem. Celé sousoší zůstává v současnosti trvale obklopeno skleněnou schránou tak, aby bylo chráněno před přímými dotyky lidí. Esquipulas je místem se známým zázračným a léčebným potenciálem, spojeným mimo jiné i s místní svatou vodou a půdou. Desetitisíce poutníků, mezi nimiž převažují ženy, přicházející sem zejména okolo svátku Černého Krista 15. ledna, ${ }^{6}$ jsou dobře doloženy od 18. století. S všeobecně vzpomínanými katolickými legendami či slavnými zjeveními a zázraky, tak jak je tomu například v prŕípadě mexického Guadalupe, se v Esquipulas ovšem nesetkáváme. ${ }^{7}$

Svatyně dnes přitahuje okolo milionu a půl poutníků ročně. Na $60 \% \mathrm{z}$ nich pochází z Guatemaly, 20 \% z Hondurasu, 10 \% ze Salvadoru, méně pak z Mexika a Spojených států amerických [Thomas - Horst - Hunter 2002: 33]. Nejvíce poutníků přichází tradičně o lednových svátcích a o Velikonocích. Tyto svátky se navíc kryjí s obdobím sucha, tj. se zemědělským rokem: návštěvnost Esquipulas $\mathrm{z}$ venkovských oblastí výrazně roste, když je zemědělských povinností nejméně [tamtéž: 40]. Další poutníci pak navštěvují některou z 200 regionálních svatyní odkazujících k Černému Kristu z Esquipulas, které jsou rozesety po celé Střední Americe, v Mexiku i USA. Jejich výskyt nejenže koreluje s rozsahem koloniální Guatemaly, ${ }^{8}$ ale dokonce prímo s primárně indiánskými oblastmi, včetně míst, kam Mayové odcházejí za prací [Horst - Thomas - Hunter 2010]. Tyto statistické údaje ukazují, že Esquipulas je tradičně především indiánským/mayským poutním místem, které přesahuje hranice jednotlivých lingvisticko-etnických skupin, a dnes dokonce různých států.

Navzdory tomu se při konkrétním výzkumu k indiánskému původu přihlásilo pouze 30 \% respondentů [Kendall 1991: 149]. Jiné výsledky ovšem přináší statistická kvantifikace venkovského a městského původu: zatímco výzkum z roku 1972 zaznamenal zhruba $70 \%$ poutníků přicházejících z venkova a $30 \%$ z měst [tamtéž: 152], výzkum prováděný

6 V kontextu katolické zbožnosti je svátek Krista z Esquipulas 15. ledna završením novény, začínající o slavnosti Zjevení Páně 6. ledna.

7 K historickému kontextu viz Pompejano [2009].

8 Audiencia de Guatemala zabírala většinu mayských oblastí, tedy nejen dnešní Guatemalu, ale také Belize, Honduras, Salvador a mexický Chiapas. 
o patnáct let později, tedy roku 1987, vykázal přesně opačný výsledek: venkovský původ přiznalo $30 \%$ poutníků, městský $70 \%$ [Thomas - Horst - Hunter 2002: 39]. Důvodem bude zřejmě skutečnost, že oněch patnáct let koresponduje s hlubokými společenskými změnami, s občanskou válkou, exodem vesničanů (především Mayů) do měst a s příchodem moderního a globalizovaného světa. ${ }^{9}$ Roku 1968 bylo Esquipulas propojeno se světem silnicí a byla zřízena pravidelná a hustá autobusová doprava do 130 kilometrů vzdáleného Ciudad de Guatemala. Započal překotný rozvoj ubytovacích a dalších služeb a s tím spojený prríliv lidí z měst, především z hlavního města a jeho okolí. Poutní místo tradičních venkovských indiánů, propojující mayské obyvatelstvo všech jeho lingvisticko-etnických skupin, se proměnilo v poutní místo většinově městských indiánů, ale především ladínů, ${ }^{10}$ spojující tentokrát guatemalský národ, a dokonce celou Střední Ameriku. Esquipulas se stává unifikujícím náboženským a kulturním symbolem Střední Ameriky, stejně jako se kdysi Guadalupe stalo symbolem Mexika.

\section{Had a Kristus}

Pro porozumění vzorcům pouti do Esquipulas je důležité zastavit se u mayské kosmologie a u toho, co ji formovalo, tedy u synkreze mayského a křestanského náboženství. ${ }^{11}$ Ve snaze prokázat možnou spojitost Esquipulas s předkolumbovskou dobou se zdůrazňuje blízkost Copánu a Quiriguá, předních starých mayských měst, a obchod s tabákem a obsidiánem, $\mathrm{k}$ němuž v těchto místech docházelo. V literatuře se dále objevuje argument, že černá barva Krista odkazuje na staré božstvo kakaa, obchodníků a lidí na cestě, v jazyce yukateko ek chuah, zobrazované v černé barvě [Osborne 1948; Borhegyi 1953; Thompson 1964]. Stejně tak se opakuje představa o indiánských sympatiích k tmavým ikonám, které lépe odpovídají jejich tmavší barvě pleti [např. Borhegyi 1954]. Je ovšem historickou realitou, že černá zpodobnění Krista či Panny Marie byla známa i v Evropě, a to již ve středověku. ${ }^{12}$ Navíc pouze deset procent latinskoamerických svatyní hostí Krista černé barvy [Nolan 1991]. Př́mou návaznost mayské a křest’anské tradice v Esquipulas lze tak stěží exaktně dokázat.

Skutečnost, že do Esquipulas směřovali a směřují lidé z celého mayského světa, vybízí k otázce, zda město není v některých svých aspektech analogií k předkolumbovským náboženským stř̌ediskům - i to však zůstává jen věcí spekulace. Samotná východní Guatemalská vysočina je především ladínskou enklávou, ačkoliv v ní tradičně žijí Mayové lingvisticko-etnické skupiny Ch’orti' (Čortíové), jíž se dostává větší antropologické pozornosti teprve v posledních letech [Metz - McNeil - Hull 2009]. Snaha o ilustraci toho, jak Čortíové chápali či chápou pout do Esquipulas, tak naráží na tristní nedostatek etnografického

\footnotetext{
9 Svou roli v rozdílnosti výsledků bude nejspíše hrát také různá metodika prováděných výzkumů.

10 Pojmů indiáni (indios nebo indígenas) a ladíni (ladinos) užívám čistě v sociokulturním významu, reflektujícím rozdíl mezi těmi, kdo jsou považováni za Maye a hovoří některým mayským jazykem, a těmi, kdo takto klasifikováni nejsou a žádným mayským jazykem nehovoří.

11 Problematika synkreze latinskoamerické a evropské náboženské tradice patří k velmi diskutovaným [viz např. Gossen - León-Portilla 1993].

12 Hlubší symbolická interpretace by mohla poukázat na význam černé barvy v křestanství obecně, v našem případě pak na její význam u místních Mayů, u nichž je černá prrítomna ve všech důležitých rituálech, kromě těch spjatých se smrtí, kde dominuje bílá [Wisdom 1940: 430].
} 
materiálu. Opř́t se lze v podstatě pouze o dva zdroje: texty Johna Foughta z 60. let a výzkum Carla Kendalla ze 70. let 20. století. ${ }^{13}$

Fought [1972: 451-461], znalec jazyka ch’orti', přepsal doslovně výpovědi indiána Isidra Gonzáleze z Jocotánu. Podle Gonzáleze tradiční lednová pout do Esquipulas trvala pět dní. V obci Olopa poutníci nakoupili svičky, které ukázali „své Matce“, nazývané také Pastora, ženě „svého Otce“, zvaného Milagroso. Tyto svíčky pak byly v Esquipulas posvěceny a odneseny domů. Po rituálním vstupu do města poutníci navštívili baziliku, někteří podnikali cestu městem po kolenou, jako výraz pokání, které zbavuje hříchů. Ostatní členové komunity ${ }^{14}$ mezitím dle prŕslušných pravidel připravovali pohoštění a chystali uvítání poutníků. Ti přinášeli do vesnice ducha Zázračného, což bývalo potvrzeno slavností, rituálním jídlem a modlitbami. Vlastní svátek se odehrává 15. ledna, neslavil se však v Esquipulas, nýbrž již doma.

González popsal i mytologické pozadí poutního místa a Černého Krista. Bůh, jehož jméno je Milagroso, nesídlil původně v lidské stavbě: stál v krajině a nesnesl žádný dotyk. Lidé mu začali stavět dům, ale on tam nechtěl zůstat. Překážkou bylo velké jezero, jehož pána - hada, bylo třeba usmírit. ${ }^{15}$ Dle vidění jedné stařeny obětovali drůbež, kadidlo a svíčky, ona žena se modlila a prosila hada o smíření. Řekla mu o novém vládci, jehož dům zde mají stavět, a had se nového pána vylekal. Lidskou práci však kazil nadále a bylo zapotřebí dalšího vidění, v němž si řekl o sluhy, živé lidské oběti, které ho nakonec udobřily. Dům pro nového boha byl dostavěn, Milagroso hada přemohl a uvázal. Had zůstal ve vodách pod bazilikou uvězněn dodnes a nečistý člověk se k němu může propadnout.

Ve své velkolepé etnografii Čortíu z 30. let se Charles Wisdom [1940] o poutích do Esquipulas nezmiňuje, zřejmě proto, že ani jeden ze svých tř́i terénních výzkumů nepodnikl v lednu, kdy k poutím docházelo; nabízí však důkladný popis dobové kosmologie. Označení ka tata', doslovný překlad španělského pojmenování Nuestro Padre (náš Otec), spojuje Wisdom [tamtéž: 391] s představu nejmocnějšího boha, pána veškerenstva, nejvyšší instance. Za nejdůležitější nativní božstvo je považován ah tcix tcan, španělsky přepisovaný jako Chicchan, tj. Hadí král či Hadí královna. Božstvo bylo zpodobňováno zpravidla jako obrovský had, někdy napůl zvíře a napůl člověk, má své nebeské a zemské variace, vždy ale bydlí v jezerech, potocích, pramenech nebo v horách, ve kterých se rodí voda [tamtéž: 392-395]. Mytický př́běh popsaný Gonzálezem lze interpretovat jako střet mayského Chicchana a křestanského Boha, kdy Bůh získává navrch, Chicchan však nadále existuje a působí, ačkoliv v podřízeném postavení. Taková interpretace zdůrazňuje synchronní perspektivu, historický moment náboženské conquisty. Na věc však lze pohlédnout i asynchronně a vyzdvihnout archetypální motiv boje boha a nestvůry (hada). ${ }^{16}$

\footnotetext{
13 Poutnictvím u Čortíu se nezabývají ani novější práce [Dary - Elías - Reyna 1998; López García - Metz 2002; Metz 2006].

14 Komunita nebo společenství (comunidad) je nejtradičnější a nejdůležitější územní, politickou, ekonomickou a kulturní jednotkou mayské společnosti. Administrativně vzato se většinou kryje s tím, co bychom nazvali obcí.

15 Jedná se o mytologický prvek, žádné jezero či vodní plocha se v těchto místech nevyskytuje.

16 Ve starém mayském náboženství by motiv mohl odpovídat dvojici Itzamna a tzv. Hlavní ptačí božstvo [Bardawil 1976].
} 


\section{Pout' ze zvyku}

Pout Čortíů do Esquipulas představuje dílo synkreze. Oba světy - ten americký, mayský, a ten evropský, křestanský - se prolnuly a vytvořily svět nový. Jak Fought [1972: 524] poznamenává, pout do Esquipulas byla pro indiány součástí nativních cyklických rituálů nového roku. O tradičním poutnictví podává svědectví i Kendall [cca 1975: 10], jenž zaznamenal skupiny vedené svými náboženskými specialisty, které přinášejí do svatyně obětiny, ale také své svaté nebo k setbě určená kukuřičná zrna. Takové věci jsou svou přítomností v chrámu posvěceny. Při postranních oltářích mohou být střeženy den a noc a následně odnášeny zpět do příslušných komunit, do nichž tak vstupuje požehnání. Moc Zázračného je dobře patrná v modlitbách prováděných po návratu z pouti, kdy lidé žádají o zdraví, úrodu, zvěř apod. Ř́kají mu: „Kudy chodíme, vidíme tě. Dej nám, co žádáme, tak aby bylo hodně jídla v našich domovech. Dopřej, abychom neměli nedostatku. Dej nám zdravého vzhledu, zdravého výrazu. Nenech vstoupit nemoci do našich domovů. Všem zlým duchům: ty máš nad nimi moc. Vyved’ je do hor, kde není lidských bytostí" [Fought 1972: 460].

Jaký je důvod takové pouti a v čem spočívá zázračnost Černého Krista? Významným prvkem popsaných poutí je pravidelnost. Poutníci přicházeli do Esquipulas skutečně pravidelně, dle svého rituálního kalendáře, zř̀ejmě v rámci obřadů příchodu nového solárního roku. Pout je v tomto ohledu srovnatelná s ostatními výročními obyčeji daných komunit [srov. Gillin 1958 (1951): 216-217]. Další nápadný prvek představuje formálnost. Pout měla svůj řád, byla součástí dalekosáhlejšího rituálního dění, které se řídilo určitými pravidly [srov. tamtéž: 237-238]. Neopominutelným prvkem je konečně také kolektivnost. Nejenže Mayové putovali ve skupinách, ale tyto skupiny byly vlastně představiteli a zástupci celé komunity, která je vyslala [srov. Palma Ramos 2001: 141].

Všechny tyto prvky souvisejí s vlastní povahou „obyčejü“ či „povinností, označovaných většinou španělským pojmem costumbre, etnologii mayské kultury tak dobře známým [např. La Farge 1947; Vogt 1976]. Jak jsme již zmiňovali, pout’ do Esquipulas se týkala celého společenství, ačkoliv se na cestu vydala jen jeho malá část. Byla tedy kolektivní, formalizovanou a pravidelnou událostí, která měla za úkol splnit povinnost vưči Zázračnému a stvrdit nerušené a zdárné pokračování světa. Účelem pouti bylo dosáhnout prosperity, úrody a zdraví komunity jako celku, stejně tak jako jednotlivých příslušníků. Důvodem, proč se Mayové obraceli zrovna na Černého Krista, se stalo to, že byl vlivem španělské christianizace vyvýšen nad stará božstva, a získal tím velkou moc.

Považujeme za obtížné nahlížet zázračnost Černého Krista prizmatem soudobého evropského myšlení. Zázrakem zde totiž není nějaké „porušení přírodních zákonư“, zázrakem se naopak stává potvrzení či dosažení stávajícího světaběhu. Skutečnost, že svět neskončí a nadejde nový rok, že ráno znovu vyjde slunce, že po období sucha přijde déšt; očekávání, že se urodí kukuřice, že bude co jíst, že nepřijde nemoc, že se domu vyhnou všechna neštěstí; a konečně víra v to, že řád nebude narušen - to všechno je nesamozřejmé [srov. López García - Metz 2002: 202]. Vědomí této nesamozřejmosti pak vede na kolektivní i individuální úrovni k úkonům a modlitbám, které, pokud se provedou správně, budou účinné. Chod světa není jistý, ve vztahu lidí a bohů je člověk aktivním činitelem, jenž se musí na obnově světa podílet. 


\section{Pout' ze slibu}

Jak ukazují novější výzkumy [Thomas - Horst - Hunter 2002; Kendall 1991], stejně tak jako moje vlastní pozorování, poutní diskurs, který je přinejmenším v dnešním Esquipulas nejčastější, se týká koncepce „slibu“. Praxe slibu (promesa) ${ }^{17}$ je v křest’anství dobře známa a lze jen stěží říci, kdy pronikla do mayské kultury či s jakou svou nativní obdobou se propojila. Pout jakožto splnění slibu zůstává živá mezi indiány stejně jako mezi ladíny. Učinění slibu je součástí určitého přání, at už adresovaného Bohu, Panně Marii či svatému, v našem případě Černému Kristu. Jde o závazek, že pokud daná božská bytost vyplní lidské přání, tento člověk splní, co přislíbil, totiž vydá se k jejímu př́bytku a vzdá jí díky. Přání, slib a dík jsou přitom aspekty jedné a téže věci; vůle lidská a božská se v ní protínají. Do Esquipulas tak přicházejí někteří lidé prosit, jiní děkovat a zanechávat svá ex-vota.

Většina poutníků dnes ovšem do Esquipulas přijíždí autobusy nebo automobily. Organizují se zájezdy, zpravidla však lidé přijíždějí v menších skupinkách rodinných příslušníků, sousedů či přátel ze své komunity. V Esquipulas stráví dva až čtyři dny a dle své majetnosti přebývají v hotelech, penzionech, levných ubytovnách nebo jednoduše venku. Centrální úkol samozřejmě představuje návštěva baziliky a přiblížení se ke schráně s Černým Kristem. O svátcích se proto čeká ve frontě mnoho hodin. Cesta vede poutníky za hlavní oltář, kde se Krista mohou dotknout, políbit ho, pokleknout před ním a vyslovit prosbu či poděkování. Další program je už individuální, takže poutník se může zúčastnit mše, zapálit svíčky, napít se svaté vody, navštívit kostel sv. Jakuba nebo kapli na nedalekém vrchu, ke které vede kř́í̌ová cesta, může zajít k blízkým jeskyním (Minas) nebo ke Kameni kmotrů (Piedra de los Compadres), ${ }^{18}$ zkamenělému „spoluotci“ a „spolumatce“, jež byli takto potrestáni za porušení zákazu sexuální zdrženlivosti. O svátcích chodí městem několik procesí, přičemž k programu poutníkủ patří též procházení tržiště, nezbytné nákupy, jídlo a pití, zábava a vůbec užívání si života a nevšedních chvil...

Poutníci přicházejí za Černým Kristem jednou či několikrát za život, a to vždy v nějaké výjimečné a konkrétní věci. Předmětem slibu bývají zdravotní problémy, rodinné a existenční záležitosti i běžné materiální potřeby. Př̀i mém pobytu u jedné indiánské rodiny z komunity Todos Santos Cuchumatán, obci nacházející se v daleké západní Guatemalské vysočině, přišla jednoho večera řeč rovněž na zázraky Černého Krista. Rodina se nedávno vydala na časově a finančně náročnou cestu do Esquipulas, jejímž motivem byl slib učiněný Normou, která si přála získat legální trvalý pobyt v USA, kde několik posledních let žila. ${ }^{19}$ Když se po letech nejistot její přání vyplnilo, považovala za nezbytné splnit svůj závazek, tj. vykonat pout za Černým Kristem a vzdát mu své díky.

Rozhovor se dále stočil také na zázraky uzdravení. Norma vyprávěla o případech, o nichž se doslechla od svých indiánských známých ve Spojených státech: nejlepší

17 Španělské slovo promesa se používá nejčastěji, ačkoliv ve španělštině existuje i slovo voto (latinský pojem votum zabíral široké sémantické pole od prosby, přání či modlitby ke slibu, zaslíbené věci nebo oběti).

18 Instituce compadres je důležitou formou nepokrevního př́buzenství, kdy se rodič a kmotr jeho dítěte stávají „spolurodiči“, což je posvátný svazek ještě většího významu, solidarity a odpovědnosti než samotné pokrevní př́buzenství. Mezi pravidla jejich vztahu patři i absolutní zákaz sexuálního poměru trestaný božskou mocí.

19 Dočasný či trvalý odchod některého př́islušníka indiánské rodiny do USA za účelem práce a finanční pomoci ostatním př́buzným je v některých regionech současné Guatemaly běžnou praxí. Závažné problémy a z nich pramenící přání týkající se emigrace do USA tvoří čím dál větší „klientelu“ nejen Krista z Esquipulas, nýbrž také lokálních indiánských svatyní, katolických kněží i mayských šamanů. 
američtí doktoři vyřkli svůj ortel nad nevyléčitelnou rakovinou, poslední slovo však měla víra v Černého Krista, jenž dokázal danou osobu nemoci zbavit. Nikdo vůbec neuvažoval o tom, že by tento Kristus takovou moc nemohl mít, že by nemohl americké doktory přemoci. Vždyt’ není důvod nevěřit: takové krásy, která je v Esquipulas k vidění; takových lidí, kteří tam přicházejí; takových zázraků, jež se udály! Ani Norma, natož pak ostatní členové rodiny, nespatřovali v podobných událostech nic nepochopitelného. Obrátím-li se na Černého Krista s prosbou, je považuji za možné, že mé přání vyplní. Pravda, jedná se o divotvorný čin, avšak zároveň je to div, na němž není nic, co by se naprosto vymykalo lidskému vědění a zkušenosti: zázraky se přeci dějí, vidíme je kolem sebe a umíme si je vysvětlit. Tyto zázraky jsou událostmi, které se neodehrávají každý den, avšak které jsou přesto jaksi v samotném řádu věcí.

Porovnáme-li pout' „ze slibu“ s poutí „ze zvyku“, najdeme mezi nimi některé rozdíly. Pout ze slibu není pravidelnou událostí, dochází k ní proto výjimečně. Také její formalizace nebývá tak výrazná, v tomto směru záleží na zvyklostech a chuti každého poutníka. Důležitá není ani kolektivnost - nikoliv z hlediska počtu účastníků, ale z pohledu svázanosti s danou komunitou a dopadu na ni. Pout ze slibu se netýká celého společenství daného jedince, nýbrž výhradně jeho samotného: předmětem pouti není kolektivní blaho a řád, ale konkrétní osobní záležitost. Konečně, míra podivuhodnosti „zázraku“ je pak v těchto různých diskursech odlišná.

\section{Zázračná půda a voda}

V předchozím textu jsem se pokusil načrtnout obraz Esquipulas a jeho dva charakteristické poutní diskursy. Svět toho, co jsem nazval „tradiční mayskou poutí, je dnes pouhým reliktem, jenž mizí stejně tak rychle, jako umírají poslední tradicionalisté. S proměnou společnosti nabývá naopak od 80. let na síle to, co by se dalo označit za „klasickou katolickou pout", která má své analogie i jinde v katolickém světě. Nicméně je dobré mít na paměti, že každý poutní projev má trochu jinou podobu, každý má svůj vlastní společenský a individuální rámec, a vytyčení obou vzorců je tak třeba chápat jako pouhou abstrakci.

Za arbitrární považujme také užívané klasifikační kritérium založené na domnělé míře podivuhodnosti z hlediska narušení obvyklého chodu světa. To, co lze v daných poutních diskursech pojímat jako zázračné, klademe na pomyslnou škálu neobvyklosti, která je zázračnosti v tomto smyslu připisována. Takto můžeme na linii „obvyklý - neobvyklý“ umístit tradiční mayskou pout před tu klasickou katolickou, což vyjadřuje skutečnost, že zázračnost v prvním př́ípadě atakuje obvyklý, pravidelný či řádný světaběh méně než v př́padě druhém. V těchto intencích pak můžeme posoudit i další vzorce, jež se v poutnictví uplatňují.

Poutní praktiku, která by se na naší škále blížila konci minimální neobvyklosti, představuje pojídání tzv. benditos („posvěcenek“), nazývaných také pan del Señor (chléb Páně). Tyto „chlebíčky“ jsou malé hliněné tabulky pocházející z místní půdy bohaté na kaolín, s vyraženými obrázky Krista, Panny Marie nebo svatých. Poutníci si je kupují, odvážejí domů a uživají je při různých zdravotních obtížích, zvláště těch ženských, nebo jednoduše pro štěstí. ${ }^{20}$ Čortíové podle Wisdoma [1940: 288] chápali benditos jako významný lék proti

20 Také praktika geofagie je známá i z Evropy, kde byla v latinském křestanství terra sigillata, půda ze svatých míst, přinášena poutníky domů a pojídána. 
všem bolestem spjatým $s$ menstruací, těhotenstvím a porodem. ${ }^{21}$ Kaolínové tablety byly žehnány katolickým knězem v bazilice a prodávány ženám po celé východní Guatemale, jež je nejprve drtily, pak míchaly s vodou a nakonec pily [tamtéž: 360]. Tato praxe se podobá západní medicíně v oné nezpochybňované samozřejmosti, s jakou lék funguje. Vzít si bendito $\mathrm{v}$ př́ípadě menstruačních potíží a s určitou dávkou jistoty očekávat zlepšení, lze bez váhání srovnat např́klad s užitím antibiotik při vysoké horečce. Ostatně staré zázračné tablety, nápoje či koření, nabízené na místních trzích, mají i své nové varianty: v této souvislosti si nelze nevzpomenout na zaručeně vědecky ověřené pastilky, masti nebo vitamíny, které dnes cestujícím vnucují snaživí obchodníci v téměř každém guatemalském autobuse [srov. Cosminsky 1986 (1983)]. ${ }^{22}$

Avšak nalézt můžeme rovněž vzorce, které se na naší pomyslné škále nápadně blíží krajnímu pólu maximální neobvyklosti. Ačkoliv by bylo možno uvést některé jednotlivé příklady $\mathrm{v}$ rámci poutnictví $\mathrm{v}$ Esquipulas, bude snad přínosnější zastavit se na moment v jednom z nejvýznamnějších novověkých evropských poutních míst, v Lurdách. Lurdská poutní tradice vznikla ještě později než ta esquipulská. Bylo to konkrétně v polovině 19. století, kdy mladičká, chudá a churavá Bernadeta zburcovala celou Francii a Evropu svými zjeveními „krásné dámy“. Její odzbrojující jednoduchost, bezelstnost a neústupnost, s nimiž o svých viděních podávala svědectví, oslovily pyrenejský lid a následně přiměly jednat nejvyšší církevní a politické autority. Z hlediska katolické církve byl Bernadetin př́íběh a lurdský př́pad vůbec interpretován jako potvrzení programu papeže Pia IX. a jeho dogmat o neposkvrněném početí Panny Marie a papežské neomylnosti. Lurdy jsou ale krystalickým příkladem dobového církevního, náboženského a kulturního milieu obecně.

Lurdské dění druhé poloviny 19. a první poloviny 20. století bylo niterně spjato se zázraky. Fenomenální procesí Nejsvětější svátosti byla příležitostí k demonstraci víry a Boží moci prostřednictvím zázraků uzdravení, ke kterým kněží vybízeli a k nimž také zhusta docházelo. Sugestivní popisy Émila Zoly [1914 (1894)] v jeho Lurdách naznačují, jak explicitní, exaltované a očekávání plné vyvolávání zázraku masami ovládanými davovou psychózou bylo. Od samotných počátků lurdské poutní tradice jsou zázraky nejpřísněji vyšetřovány místní Lékařskou kanceláří, a právě lékaři, tito poslové přírodní vědy, hrají $\mathrm{v}$ této tradici zásadní roli. Lurdy byly viditelným a přesvědčivým nástrojem snahy obhájit katolicismus, existenci a moc Boží, a v neposlední řadě primát víry nad rozumem. Autoritou, která tu měla paradoxně působit, byla lékařská věda, ta instance ze všech nejateističtější, významný atribut osvícenské racionality. Právě tento proces je př́kladným vyjádřením pojetí zázraku, jak ho moderní Evropa chtěla mít. Z bigotně deistické, osvícenské Francie, pro niž bylo aktivní působení Boha na zemi směšnou pohádkou, vyhřezla nespoutaná iracionalita živoucího zázraku. Došlo k tomu v kultuře, která - alespoň v některých svých podobách - vytyčila ostré dichotomie v podobě polarit rozum/víra a věda/náboženství, jejichž prvky mohou být jen nepřátelské a vzájemně se vylučující.

Lurdy byly ve svém „klasickém obdobi“ ukázkou toho, jak lze zázrak chápat jako porušení př́rodních zákonů. Po požití svaté vody nebo při účasti na lurdském procesí může dojít z minuty na minutu ke zlepšení či odbourání kterékoliv nemoci nebo hendikepu,

${ }^{21}$ Chemické analýzy prokázaly, že minerální složení benditos není nepodobné př́pravkům doporučovaným těhotným ženám západní medicínou [Hunter - Kleine 1984].

22 Věc samozřejmě náleží do kontextu dalších představ a praktik tradiční mayské medicíny [např. Fabrega - Silver 1973; Huber - Sandstorm 2001]. 
ačkoliv z lékařského hlediska se jedná o nepochopitelnou věc. Milost Boží se projeví jen výjimečně a způsobem, který nepatří do tohoto světa a je v rozporu s jeho zákonitostmi a fungováním. I tento obraz měl však časem doznat změn. John Eade [1991: 60-63] zdůrazňuje, že od 80 . let 20. století Lurdy prožívají zásadní reinterpretaci nejenom zázraku, ale vůbec celého pojetí pouti. Tyto změny jsou patrné jak při organizovaných koupelích v lurdské vodě, tak během procesí. Zatímco dříve rituál v lázni zahrnoval např́íklad recitování předepsaných modliteb, pití zázračné vody nebo individuální úkony typu omytí růžence, jsou dnes poutníci před koupelí vyzýváni ke vzpomínce na svůj vlastní křest a k reflexi významu a důležitosti této svátosti. Oficiální církevní pojetí je přitom často v rozporu s osobním prráním a potřebami poutníků. Podobně procesí Nejsvětější svátosti již nejsou uhrančivým očekáváním zázraku, nýbrž střízlivou reflexí nemoci a utrpení ve vztahu k svátostně zprostředkované milosti. Pokud se má za to, že k zázraku přeci jen došlo, emoce jsou usměrněny a daný člověk je rychle odveden do Lékařské kanceláře $\mathrm{k}$ výslechu a vyšetření [tamtéž: 68-73].

Ačkoliv i dnes přijíždí většina poutníků do Lurd v konkrétní zdravotní záležitosti, snaží se církevní autority spojení koupelí a pití vody se zázračným uzdravováním bagatelizovat. Jakkoli jsou postavy Panny Marie a svaté Bernadety nadále důležité, jsou dnes zastíněny významem přináležitosti k církvi a postavou Krista. Pravou podstatou pouti má být tak kontemplace nad svátostmi křtu, smíření a přijímání. Nemocní jsou ted'v první řadě příslušníky církve, které spojuje lidská hříšnost a potřeba Boží milosti, a jejich nemoc je zapotřebí chápat v tomto kontextu. Andrea Dahlbergová [1991: 38] upozorňuje na to, že v Lurdách vlastně dochází k jakémusi zhodnocení a posvěcení tělesného utrpení: bud' v jeho povznášejícím připodobnění k utrpení Ježíšovu, nebo v jeho vztahu k Boží vưli, jejíž důvody a záměry nelze dohlédnout. $\mathrm{V}$ obou př́ípadech nabývá utrpení zásadní hodnoty a stává se znamením; je jakýmsi stigmatem, se kterým je třeba se smírit a využít ho. Toto pojetí se pak dostává do ostrého konfliktu s původně utilitárním přáním zázraku. Hlavním motorem této reinterpretace pouti je tedy snaha o její náboženské a symbolické definování na úkor onoho pověrečného, magického a instrumentálního. $\mathrm{V}$ tom také spočívá příčina skepticismu k možnosti zázraku, jenž je tak vlastně nedůležitý, ba nevítaný. Lze považovat za ironii osudu, že Lurdy, které vznikly jako antiteze k osvícenskému světu, dospěly nakonec $\mathrm{k}$ některým $\mathrm{z}$ ideálů osvícenství, tentokrát skrze modernizaci církve v podobě II. vatikánského koncilu. ${ }^{23}$

Výše uvedené skutečnosti naznačují postup od „zázračného“ k „obětnímu“ [Dahlberg 1991: 49] či ke „svátostnímu“ [Eade 1991: 65] diskursu. Jak Dahlbergová [1991: 46] na konkrétních etnografických výzkumech ukazuje, vyskytují se v Lurdách i skupiny a jednotlivci, kteří už zázrak opravdu neočekávají. Ovšem tělesně postižený člověk, jenž je ve svém běžném životě na okraji společnosti, se v Lurdách octne v centru dění a nachází novou sociální roli a status; nejenže se stává „normálním“, ale dokonce tím významnějším, nesoucím v sobě něco ze svatosti. Zázrak je čím dál méně a méně dosažitelným, něčím, co je zcela mimo předvídatelný a obvyklý chod světa. Ve snaze podat extrémní příklad tohoto pojetí zázraku je možné vzpomenout na film Lurdy Jessiky Hausnerové. ${ }^{24}$ Hlavní hrdinka

\footnotetext{
23 Victor Turner by v této souvislosti nejspíše hovořil o „zestrukturnatěni“ původně antistrukturního, liminálního poutního a rituálního dění.

24 Lourdes, Rakousko 2009, scénář a režie Jessica Hausner.
} 
Christine jede do Lurd, což pro ni jako člověka upoutaného na vozík představuje jednou $\mathrm{z}$ mála př́ležitostí, jak se někam podívat. Vlastně tam nechtěla a $\mathrm{v}$ zázraky nevěří, je to však ona, kdo je vyznamenána milostí a začne chodit. Proč zrovna ona a ne ten, kdo na tom byl zdravotně daleko hưře, nebo někdo, kdo žije tím nejpříkladnějším životem, nebo ten, kdo v zázrak věří, vroucně o něj prosí a doufá v něj? Jak to, že neexistuje žádné lidské vodítko, žádná poznatelná logika, kudy se ubírají cesty milosti? Zázrak se v tomto kontextu nachází mimo jakékoli lidské představy a snažení, zcela mimo určitý prostor a čas. Je něčím nepochopitelným a vrchovatě podivuhodným, něčím, co se může odehrát kdekoli a kdykoli a zcela nezávisle na člověku.

\section{Závěr}

Koncept zázraku, jak jej známe z moderní západní kultury, je nesamozřejmý a svým způsobem unikátní. Vychází z formulace pojmu „přírodní zákon“, která se objevila někdy v 17. století u Descarta a v jeho myslitelském okolí [Kratochvíl 1994: 17], a dále pak z osvícenského světového názoru, jenž na jedné straně Bohu přiznal stvoření světa s jeho obecnými zákony, na straně druhé mu ale upřel zasahování do něj. Přírodní věda nakonec škrtla i inteligentního Boha stvořitele a zázrak definovala jako jev odporující empirické realitě a př́rodě, tedy jako něco neexistujícího.

Jak patrno, právě v této kultuře vznikly Lurdy. Bůh a zázrak pro poutníky dál existují, ovšem Bůh je chápán jako stvořitel přírodních zákonů, jenž má také moc tyto zákony dle svého uvážení porušit. $V$ tomto ostrém dualismu přirozeného a nadpřirozeného či racionálního a iracionálního se Bůh zázrakem legitimuje, dokazuje svou existenci, moc a vưli. Nejenže Lurdy kopírovaly dobový způsob myšlení, ale také se jeho největší autoritou, totiž vědou, ospravedlňovaly: ostatně teologická komise posuzující pravost zázraku byla a zůstává ještě prrísnější než komise lékařská. Dnes je zázrak v Lurdách upozaděn, avšak tím víc se stává jedinečnou událostí, výjimečnou Boží manifestací. Nachází se mimo obvyklý rád věcí, je tedy absurdní, a přeci se v něj věří.

„Proč je víc než pravděpodobné, že všichni lidé musí zemřít, že olovo nemůže samo zůstat trčet ve vzduchu, že oheň stravuje dřevo, ale voda jej hasí, ne-li proto, že všechny tyto děje jsou podle nás $v$ souladu se zákony př́rody a že k tomu, aby se přestaly dít, by bylo třeba porušení těchto zákonů nebo jinými slovy zázrak? Nic není považováno za zázrak, když to nastane v rámci běžného chodu prrírody. Není to zázrak, když muž zdánlivě zdravý náhle zemře, nebot taková smrt, i když neobvyklejší než jiné, byla nicméně již často pozorována. Ale byl by to zázrak, kdyby mrtvý začal zase žít, protože to nebylo pozorováno nikdy v žádné době a žádné zemi. Musí tu tedy být uniformní zkušenost proti každé zázračné události, jinak by si dotyčná událost nezasloužila toho jména, “ píše David Hume [1996 (1748): 159-160; kurzíva je moje].

Nechme ted’ stranou Humovu filosofickou skepsi a jeho radikální nedůvěru v zázraky; povšimněme si však, že Hume v tomto textu (na rozdíl od Descarta) vlastně definuje zázrak kulturně: zázrak je něco, co odporuje uniformní zkušenosti s běžným děním, něco, co podle nás nesouhlasí se zákony přírody. Zázrak tedy není porušením přírodních zákonů samých (tj. „z pohledu Božího oka“, anebo vědy, která neomylně tyto Boží zákony objevuje), nýbrž je narušením obvyklého chodu světa, jak si ho za daného (tj. kulturně ukotveného) stavu poznání a myšlení představujeme. 
Pro Maye je jejich medicína do určité míry zkušenostně účinná, stejně jako ta evropská pro nás; západní psychologie nebo psychiatrie může mít podobnou úspěšnost jako mayské poutní či šamanské rituály. Vypadá to, jako by si každá kultura z př́rodních zákonů vybrala svůj díl, který pokládá za „přirozený“, zatímco jiným nevěří, anebo je označí za „Zázračné“. Možná, že „primitivové“ nejsou ani tak méně rozumní, jako spíše rozumní jinak. Na různých zázračných diskursech v Esquipulas jsme viděli, že zázrak je chápán jako integrální součást př́írody a světa, jako něco více či méně neobyčejného a podivuhodného, avšak pochopitelného. Ostatně slovo mayibal, pocházející z dnes nejpočetnějšího mayského jazyka k’iche’, lze přeložit spíše jako „div“ než „zázrak“; spř́ízněné sloveso mayij znamená „divit se“, „obdivovat“, „být překvapen“ [Christenson 2004]. Nicméně ani stará evropská kultura nepřikládala zázraku dnešní významy. Starořecká slova semeion, teras a thauma, respektive latinská slova signum, prodigium a miraculum zázrakem míní „znameni“, „div“ nebo „něco neobyčejného, podivuhodného“. Pojem miraculum, z něhož pochází slovo pro zázrak v mnoha evropských jazycích, znamená jednoduše to, „co je hodné vidění či podivení".

Robert Shanafelt [2004: 322], jeden z mála antropologů, jež konceptualizovali zázrak, se domnívá, že to je právě latinský pojem miraculum, který se pro antropologická mezikulturní studia ukazuje jako prŕhodnější. Do současného jazyka ho překládá jako „div“.25 Univerzalistických definic lze nalézt mnoho: zázrak je intervence neviditelného Boha do viditelného světa, demonstrace nadřazené božské síly vưči té podřazené lidské, vítězství náboženství nad magií, porušení přirozených zákonů nadpřirozenou mocí, vpád iracionálna a paranormálna do světa osvícené racionality, popření empirické reality nadsmyslovou imaginací atd. Stručně řečeno, pojmy zázrak a přírodní zákon jsou v naší kultuře natolik zatíženy „karteziánským obratem“ a nesou tak specifické významy, že jsou pro antropologii přinejmenším nevhodné a zavádějící.

V této práci jsem chtěl zázrak či div nahlédnout prizmatem klasifikace založené na domnělé míře podivuhodnosti z hlediska narušení řádu světa. Na příkladech z Esquipulas a Lurd jsem si všímal toho, jak obvyklým, nebo naopak neobvyklým se zázrak v určitém diskursu poutníkům jeví, respektive jak moc pro ně zázrak náleží nebo nenáleží do řádného, pravidelného a smysluplného chodu světa. Zázrakům jsem se snažil porozumět jako divům v kontextu daných kultur. Pokud mnozí definují zázrak ve vztahu k „přírodnímu zákonu“, já jsem se pokusil definovat div prostřednictvím „obvyklého světaběhu“. Lidé se diví, jsou pochybovační a skeptičtí všude na světě a stejně tak rozlišují mezi obyčejným a neobyčejným. Právě tato psychologická danost údivu a rozlišování stojí za rozmanitými pojetími zázraku; stává se bází, jež se vyjevuje a realizuje ve specifických kulturních vzorcích odrážejících specifické vědění a zkušenost.

Struktura zázraku umožňuje rovněž inverzní představy, totiž uvědomění si nesamozřejmosti zdánlivě samozřejmého. Tradiční mayské pojetí pouti do Esquipulas, nalézající svůj smysl v očekávání příchodu jara, tj. období deštů, a v naději v pokračování života a kosmu, je toho dobrou ukázkou. Zázrak představuje pro člověka něco podivuhodného, vycházejícího $\mathrm{z}$ vědomí nesamozřejmosti některých věcí či jevů. K zázraku se v tomto smyslu vztahuje i moderní doba. Ve své Písni o Bernadettě prezentuje Franz Werfel [2007 (1941): 194] výjev údivu a nadšení pyrenejského lidu nad zázrakem Bernadetina objevu

25 V anglickém originále „marvel“. 
uzdravujícího pramene v massabiellské jeskyni a přihlížejícímu spisovateli a básníku Hyacinthovi de Lafite vkládá do úst tato slova: „A co tamhle ten měsíc, pánové? Není zázrak i ta luna, ta mrtvá, věčně kolem nás kroužící hvězda? Velké zázraky vidět nechcete, proto potřebujete malé..."

Ostatně kolizi různých podob struktury zázraku názorně předvádí známá anekdota, jako šitá na míru protestantské Americe: K domu jednoho muže se blíží povodeň. Policista ho varuje a nabízí mu urychlený odvoz autem. Muž však odmítne: „Věrím v Boha, on mě zachrání." Zanedlouho se přižene voda a muž vyleze na střechu svého domu. Tu zaslechne hasiče, jenž na něj z člunu volá, zda nechce pomoci. „Doufám v Boha,“ odpoví muž, „on mě zachrání. “Voda stoupá a muž musí vylézt až na komín. V tu chvíli přikrouží helikoptéra se záchranářem nabízejícím muži poslední šanci pohromě uniknout. Ten však neochvějně trvá na svém: „Spoléhám na Boha, on mě zachrání.“ Krátce nato voda pohltí i komín a muž se utopí. Přijde do nebe a táže se Boha: „Bože, věřil jsem, že mě zachráníš. Proč jsi to neudělal?“ A Bůh odpoví: „Poslal jsem ti auto, člun a helikoptéru: na co jsi čekal - snad na zázrak?"

\section{Literatura}

Bardawil, Lawrence W. [1976]. The Principal Bird Deity in Maya art: An iconographic study of form and meaning. In. Robertson, Merle Greene (ed.). The art, iconography \& dynastic history of Palenque III. Pebble Beach: Robert Louis Stevenson School, s. 195-209.

Borhegyi, Stephen F. de [1953]. The miraculous shrine of Our Lord of Esquipulas in Guatemala and Chimayo, New Mexico. El Palacio 60, s. 83-111.

Borhegyi, Stephen F. de [1954]. The cult of Our Lord of Esquipulas in Middle America and New Mexico. El Palacio 61, s. 387-401.

Cosminsky, Sheila [1986 (1983)]. El pluralismo médico en Mesoamérica. In. Kendall, Carl - Hawkins, John - Bossen, Laurel (eds.). La herencia de la conquista: Treinta años después. México: Fondo de Cultura Económica, s. 172-185.

Dahlberg, Andrea [1991]. The body as a principle of holism: Three pilgrimages to Lourdes. In. Eade, John - Sallnow, Michael J. (eds.). Contesting the sacred: The anthropology of Christian pilgrimage. London New York: Routledge, s. 30-50.

Dary, Claudia - Elías, Sílvel - Reyna, Violeta [1998]. Estrategias de sobrevivencia campesina en ecosistemas frágiles: Los ch'orti' en las laderas secas del oriente de Guatemala. Guatemala: FLACSO.

Eade, John [1991]. Order and power at Lourdes: Lay helpers and the organization of a pilgrimage shrine. In. Eade, John - Sallnow, Michael J. (eds.). Contesting the sacred: The anthropology of Christian pilgrimage. London - New York: Routledge, s. 51-76.

Evans-Pritchard, Edward E. [1937]. Witchcraft, oracles and magic among the Azande. Oxford: The Clarendon Press.

Fabrega, Horacio - Silver, Daniel B. [1973]. Illness and shamanistic curing in Zinacantan: An ethnomedical analysis. Stanford: Stanford University Press.

Fought, John G. [1972]. Chortí (Mayan) texts. Philadelphia: University of Pennsylvania Press.

Geertz, Clifford [2000 (1973)]. Interpretace kultur. Praha: SLON.

Gillin, John [1958 (1951)]. San Luis Jilotepeque: La seguridad del individuo y de la sociedad en la cultura de una comunidad guatemalteca de indígenas y ladinos. Guatemala: Editorial del Ministerio de Educación Pública.

Gossen, Gary H. - León-Portilla, Miguel (eds.) [1993]. South and Meso-American native spirituality: from the cult of the feathered serpent to the theology of liberation. New York: Crossroad.

Harris, Ruth [1999]. Lourdes: Body and spirit in the secular age. New York: Viking Press. 
Horst, Oscar H. - Thomas, Robert N. - Hunter, John M. [2010]. Difusión del culto al Cristo Negro Crucificado de Esquipulas. Mesoamérica 31 (52), s. 143-158.

Huber, Brad R. - Sandstrom, Alan R. (eds.) [2001]. Mesoamerican healers. Austin: University of Texas Press.

Hume, David [1996 (1748)]. Zkoumání o lidském rozumu. Praha: Nakladatelství Svoboda.

Hunter, John M. - Kleine, Renate de [1984]. Geophagy in Central America. Geographical Review 74 (2), s. $157-169$.

Christenson, Allen J. [2004]. K'iche'-English dictionary and guide to pronunciation of the K'iche'-Maya alphabet. Dostupné na http://www.famsi.org/mayawriting/dictionary/christenson (staženo 2. 11. 2011).

Kendall, Carl [cca 1975]. Esquipulas. Rukopis uložený v knihovně CIRMA, Antigua Guatemala.

Kendall, Carl [1991]. The politics of pilgrimage: The Black Crist of Esquipulas. In. Crumrine, N. Ross Morinis, Alan (eds.). Pilgrimage in Latin America. Westport: Greenwood Press, s. 139-156.

Kratochvíl, Zdeněk [1994]. Filosofie živé prírody. Praha: Herrmann a synové.

La Farge, Oliver [1947]. Santa Eulalia: The religion of a Cuchumatan Indian town. Chicago: University of Chicago Press.

Lévi-Strauss, Claude [2006 (1958)]. Strukturální antropologie. Praha: Argo.

López García, Julián - Metz, Brent E. [2002]. Primero Dios: Etnografía y cambio social entre los mayas ch'orti's del oriente de Guatemala. Guatemala: FLACSO.

Metz, Brent E. [2006]. Chorti'-Maya survival in eastern Guatemala: Indigeneity in transition. Albuquerque: University of New Mexico Press.

Metz, Brent E. - McNeil, Cameron L. - Hull, Kerry M. (eds.) [2009]. The Ch'orti' Maya area: Past and present. Gainesville: University Press of Florida.

Nolan, Mary Lee [1991]. The European roots of Latin American pilgrimage. In. Crumrine, N. Ross - Morinis, Alan (eds.). Pilgrimage in Latin America. Westport: Greenwood Press, s. 19-49.

Osborne, L. de Jongh [1948]. Pilgrims' progress in Guatemala. Bulletin of the Pan American Union, s. $135-142$.

Palma Ramos, Danilo A. [2001]. Así somos y así vivimos los Chórti. Guatemala: Universidad Rafael Landívar.

Pompejano, Daniele [2009]. El dios negro de los hombres blancos. Mesoamérica 30, 51, s. 123-149.

Radin, Paul [1937]. Primitive religion: Its nature and origin. New York: Viking Press.

Scott, Robert A. [2010]. Miracle cures: Saints, pilgrimage, and the healing powers of belief. Berkeley: University of California Press.

Shanafelt, Robert [2004]. Magic, miracle, and marvels in anthropology. Ethnos 69 (3), s. 317-340.

Thomas, Robert N. - Horst, Oscar H. - Hunter, John M. [2002]. Pilgrim networks of the shrine of Esquipulas, Guatemala. Journal of Cultural Geography 20 (1), s. 27-49.

Thompson, J. Eric S. [1964]. Trade relations between the Maya highlands and lowlands. Estudios de Cultura Maya 4, s. 13-48.

Turner, Victor W. [2004 (1969)]. Průběh rituálu. Brno: Computer Press.

Vogt, Evon Z. [1976]. Tortillas for the gods: A symbolic analysis of Zinacanteco rituals. Cambridge: Harvard University Press.

Werfel, Franz [2007 (1941)]. Píseň o Bernadettě. Praha: Vyšehrad.

Wisdom, Charles [1940]. The Chorti Indians of Guatemala. Chicago: The University of Chicago Press.

Zola, Émile [1914 (1894)]. Lourdy. Praha: Nakladatelství Jos. R. Vilímek.

Jan Kapusta ${ }^{*}$ 1985) vystudoval etnologii na Filozofické fakultě Univerzity Karlovy v Praze. Na stejném pracovišti pokračuje v doktorském programu. Studoval na Universidad Complutense v Madridu (2007-2008) a University of Roehampton v Londýně (2012). Prováděl terénní výzkumy ve Španělsku (2006 a 2007) a v Guatemale (2009). Zabývá se antropologií náboženství (poutnictví, obětní rituály) a etnologií Latinské Ameriky (mayská kultura). 